\title{
LIETUVOS STUDENTŲ EMIGRACINĖS NUOSTATOS IR JAS LEMIANTYS VEIKSNIAI
}

\author{
Gediminas Merkys, Viktorija Baršauskienė, Dalia Antinienė \\ Kauno technologijos universitetas, Kaunas, Lietuva
}

Gediminas Merkys. Profesorius socialinių mokslų (edukologijos) habilituotas daktaras. Kauno technologijos universiteto Sociologijos katedros vedejas. Mokslinių tyrimų kryptis — socialinių tyrimų metodologija.

\begin{abstract}
SANTRAUKA
Straipsnyje pateikti Lietuvos studentu emigraciniu nuostatu empirinio tyrimo duomenys. Socialines nuostatos tirtos naudojant uždaro tipo anonimini klausimyna. Klausimynas sudarytas taip, kad jame išryškètu studentu emigraciniai ketinimai (priklausomas kintamasis) ir kiti veiksniai, kurie hipotetiškai mastant gali turèti jiems įtakos bei juos paaiškinti (nepriklausomu kintamuju blokas). Iš viso apklausta 712 studentu. Tyrimas apima 5 šalies miestus, 9 universitetus, 2 kolegijas ir 2 aukštesniasias mokyklas. Greta pagrindinès imties papildomai suformuota 290 respondentu ,, kontrastine“"imtis, apimanti kitas amžiaus ir socialinio statuso grupes: nuo moksleiviu ir brandaus amžiaus suaugusiuju iki pagyvenusiu asmenu, iskaitant politinius kalinius ir tremtinius.

Priklausomas kintamasis konkretizuotas 14 klausimu, iš kuriu faktoriu analizès būdu sudaryti trys psichometriniai indeksai. Nepriklausomas kintamasis konkretizuotas 571 klausimu. Ǐ̌ šiu klausimu daugiapakopès faktoriu analizès būdu sudaryta nuo keliolikos iki keliasdešimties psichometriniu indeksu. Sutankintos priklausomojo ir nepriklausomojo kintamuju struktūros vèliau statistiškai asocijuotos tarpusavyje, panaudojant ivvairius metodus - koreliacinę, regresine, dispersinę analizę ir $k t$.

Vertindami savo emigracinius ketinimus, studentai salygiškai linkę atstovauti racionaliam požiūrį $\mathfrak{z}$ šl reiškiní, o ne ekonomiškai motyvuotam „,kosmopolitiniam“. Pastarajam linkę pritarti jaunesni ir atitinkamai mažiau išsilavine studentai. Emigraciniu ketinimu kontekste moterys linkusios užimti etnocentristine, o vyrai salygiškai labiau linke užimti ekonomiškai motyvuota pozicija. Klasteriné analize leido nustatyti du skirtingus (pagal emigracinius ketinimus) studentu tipus — „,mobiluji kosmopolitini“ (paplitimas — apie 48,5\%) ir ,, sèsluji etnocentristini““ (paplitimas - 51,5\%). Paaiškejo, kad studentu emigraciniai ketinimai teoriškai prasmingai ir statistiškai patikimai siejasi su ¿̇vairiais kintamaisiais, parodančiais studentu asmenybinius parametrus ir psichosocialine situacija.
\end{abstract}

Raktažodžiai: emigracinès nuostatos; kosmopolitinis, racionalus ir etnocentristinis požiūris ì emigracija.

\section{IVADAS}

$\mathrm{M}$ igracija — tai sudètingas, daugiamatis socialinis procesas, atlikęs ir toliau atliekantis svarbu vaidmeni žmonijos vystymesi. Jis skatina tam tikrų igūdžių mainus, plečia valstybiu kultūrini potencialą ir pan. Kita vertus, migracija tikslo šalyse gali kelti ekonominių, socialiniu ir politinių sunkumų arba ịtampų. Kilmès šalyse masinè migracija pavojinga dèl to, kad ji skatina populiacijos senèjimą, ,protu nutekejjimą“" ir pan.

Tarptautinès migracijos mastai vis labiau plečiasi, štai, pavyzdžiui, Šiaurès Amerikoje imigrantų skaičius per dešimtị metų išaugo 13 milijonų, Europoje -8 milijonais žmonių (International
Migration Report, 2005). Tarptautinès Migracijos Organizacijos (TMO) duomenimis, prognozuojama, kad 2050 metais pasaulyje migrantų skaičius pasieks net 250 milijonu.

Per penkiolika nepriklausomybės metu Lietuvos gyventojų migracija i Vakarų šalis taip pat išaugo. 1999 m. iš Lietuvos emigravo 1369, 2001 m. - 7253, o 2003 m. - net 11032 šalies gyventojai (Lietuvos statistikos metraštis, 2001; Tarptautine migracija, 2004). Tačiau tai tik oficialioji statistika, toli gražu neparodanti tikro emigracijos iš šalies vaizdo. Nelegalioji emigracija Lietuvoje nefiksuojama, bet spejama, kad nuo 1990 
metų, nepriklausomybės laikotarpiu, $\mathfrak{i}$ Vakarus jau išvyko daugiau kaip 500 tūkstančių žmonių.

Migracija yra vienas iš socialinių reiškinių, i kuri galima pažvelgti iš filosofijos, demografijos, teisès, istorijos ir iš daugybès kitų mokslų poziciju, todèl jos problemomis domisi iqvairiu sričių mokslininkai. Visgi, ko gero, pati universaliausia migracijos studiju prieiga - ekonominè. Šiuo požiūriu migracija suprantama kaip procesas, stimuliuojamas poreikio turèti pragyvenimo šaltini, todèl ji yra susijusi su darbo rinka. Suprantama, ekonominè prieiga nèra vien tik ekonomikos mokslo prerogatyva. Šios migracijos aiškinimo prieigos laikosi daugybè autorių, kaip antai K. Marks, A. Smith, K. Teylor ir kt.

Pereinant prie Lietuvos realijų reikia pastebèti, kad šalies gyventojų emigracija dažnai siejama kaip tik su ekonominiais poreikiais. Ekonominiai migracijos motyvai nustatyti daugybe mokslinių tyrimu (Kuzmickaite, 1994, 1996; Kazlauskienè, 2001 ir kt.). Apibendrintai Lietuvos emigrantai kartais netgi vadinami ,ekonominiais migrantais“.

Statistiškai užfiksuota, kad iš Lietuvos išvyksta daugiausia asmenys iki 30 metų. Kaip rodo pasaulinè praktika, tai būdinga visoms migracijos formoms visose šalyse (Sipavičienè, Tureikyte, 2000). Jaunimas, palyginti su kitomis amžiaus grupėmis, yra kur kas mobilesnis: jauni žmonès nèra susaistyti šeimyninių, profesinių, finansiniu ir kitų ryšiuc, todèl yra daug laisvesni rinktis gyvenamają vietą (šalị). Be to, apsisprendę išvykti jie, lyginant su vyresniaisiais, turi daug daugiau galimybių natūralizuotis, integruotis naujoje kultūrinėje terpèje. Žmogiškujų išteklių plètotès požiūriu grèsminga tai, kad iš Lietuvos, demografine prasme „pagyvenusių žmonių šalies“, masiškai emigruoja jauni žmonès. O ypač nerimą kelia, kad išvyksta intelektualiausiai jaunimo daliai priklausantys asmenys - studentai.

Taigi iš dalies galima kalbèti ir apie jaunimo intelektualinę emigraciją, kitaip vadinamą ,protu nutekejjimu“". Plačiausiaja prasme intelektualine vadinama tokia emigracija, kai kilmès šalị palieka kvalifikuoti specialistai, dirbantys intelektini, kūrybinį darbą arba potencialūs specialistai. Viena iš potencialių specialistų grupių ir yra studentija.

„Protų nutekejimo“" problema pastaruosius tris dešimtmečius mokslo pasaulyje ypatingai domimasi. Užsienyje nuolatos leidžiama daugybẻ šio klausimo analizei skirtu darbu (Гохберг и др., 1994; Eckstein,

\footnotetext{
1 „Proto nutekejjimo“ (brain drain) sąvoka pirmą kartą pavartota 1962 m., aprašant Didžiosios Britanijos mokslininkų, inžinierių ir technikų emigraciją i JAV.
}

Weiss, 1997; Pellegrino, 2001 ir kt.). Lietuvoje „protu nutekejjimo“" problema taip pat aktuali (Stankūnienè, 1996; Kazlauskienė, 2001; Jucevičienè ir kt., 2002 ir kt.). Moksle yra susiklosčiusios dvi intelektualinès migracijos koncepcijos: pasikeitimo žiniomis (patirtimi) ir „,protų švaistymo“. Pastarajam požiūriui atstovaujantys autoriai teigia, kad ,protu nutekejjimas“ griauna šalies socialinę-ekonominę plètra, smukdo gyvenimo lygi (Bernstein, Shuval, 1996).

Su tuo, ko gero, privalu sutikti. Studentijos emigracija yra daugiamatis procesas, kuriame persipina visas mazgas skaudžių socialinių problemų: demografiniai nuostoliai, ,protų nutekejjimas“ ir tautinio identiteto praradimas. Valstybe į kiekvieno Lietuvos studento išmokslinimą investuoja didžiules lèšas, bet dèl emigracijos savo investicijų dažnai netenka. Kartais manoma, kad užsienyje igiję kvalifikaciją, suformavę socialinį tinklą ir susikūrę ekonomini pamatą išvykusieji sugrišs. Lietuva jau penkiolika metu nepriklausoma valstybè, bet reemigracijos tendencijos kol kas nèra pastebimos. Priešingai, spartėjančiu globalizacijos ir eurointegracijos procesų kontekste pagristai galima tiketis dar didesnio emigracijos protrūkio. Todèl šiuo metu verta kalbèti ne apie pozityvius emigracijos aspektus, bet apie žalą tiek kiekvienam išvykstančiajam atskirai, tiek Lietuvai apskritai. Taigi jaunų žmonių masinę emigraciją, ko gero, galètume traktuoti kaip akivaizdžiai negatyvų socialinį reiškini, kuriuo privalu domėtis.

Psichosocialinius fenomenus, tarp jų ir emigracines nuostatas, kaip žinoma, galima tirti remiantis arba Etic, arba Emic ${ }^{2}$ metodologine koncepcija (Thomas, 1993; Matsumoto, 2000). Nè viena iš jų moksle nèra igijusi ryškesnès persvaros. Visgi, kalbant apie emigracinius ketinimus, privalu rinktis Emic koncepciją, leidžiančią atskleisti šių nuostatų kultūrini specifiškumą. Žvelgiant iš šios metodologinès koncepcijos pozicijos, statistiniai dèsningumai ir teoriniai apibendrinimai, nustatyti kitose šalyse bei kultūrose, negali būti automatiškai perkeliami Lietuvos gyventojams. Todèl labai svarbūs dabartines Lietuvos realijas atitinkantys tyrimai, kurie galètų padèti atskleisti kultūriškai specifišką emigracinių nuostatų fenomeno raišką šalyje.

Tyrimo tikslas - atlikti masini atrankini Lietuvos studentų populiacijos socialinių nuosta-

2 Etic metodologinè koncepcija teigia, kad psichosocialiniai fenomenai yra universalūs, jie gali būti aptikti, ištirti ir tarpusavyje palyginami vieninga metodologija. Emic metodologinè koncepcija laikosi priešingos pozicijos: psichosocialiniai fenomenai anaiptol nèra universalūs, sunkiai pasiduoda tarpkultūriniam apibendrinimui ir yra kultūriškai specifiški. 
tų apklausos tyrimą, kuriuo būtų: a) išnagrinètas studentų emigraciniu nuostatų turinys ir raiškos ypatumai; b) atskleisti šias nuostatas lemiantys ¿̇vairūs psichosocialiniai veiksniai.

\section{Tyrimo klausimai ir uždaviniai.}

1. Klausimas. Kokie konkretūs rodikliai nusako studentų emigracinių nuostatų turini? Kokia yra Lietuvos studentų emigracinių nuostatų raiška, kaip stipriai šios nuostatos išreikštos pagal atskirus rodiklius? Šių klausimų sprendimas implikuoja porą konkrečių mokslinių uždavinių: 1) parengti socialinių nuostatų ir nuomonių klausimyną, matuojanti ivairias emigracinių nuostatu dimensijas; 2) atlikti Lietuvos studentų populiacijos masinę apklausą ir statistinius duomenų skaičiavimus.

2. Klausimas. Kokie psichosocialiniai veiksniai (lytiškumas, tautybè, vietovè, amžius, kultūrinis kapitalas, vertybinès orientacijos, socialinès fobijos, socialinis tinklas, politinès ir religinès nuostatos, buvimo užsienyje patirtis, edukacinè biografija, profesinès aspiracijos, autokoncepcija ir kt.) lemia studentu emigracines nuostatas in corpore ir pagal atskiras dimensijas? Kurie veiksniai daro itaka, o kurie visai nesusiję? Šių klausimų sprendimas taip pat apima kelių konkrečiu tyrimo uždavinių realizavimą: 1) parengti atitinkamus socialinių nuostatų ir biografinius klausimynus; 2) remiantis šiais klausimynais, atlikti studentų populiacijos analizę.

\section{TYRIMO ORGANIZAVIMAS IR METODAI}

Tyrimo dalyviai. Emigracinių nuostatų tyrimo rezultatai gauti apklausus studijuojanti jaunimą. Apklausti kai kurių universitetų (Vilniaus pedagoginio, Klaipėdos, Vytauto Didžiojo, Kauno technologijos universiteto, Aukštosios vadybos mokyklos (ISM), VU Kauno humanitarinio fakulteto, Kauno tarpdiecezinès kunigu seminarijos, KTU Panevèžio fakulteto), kolegijų (Vakarų Lietuvos verslo, Marijampolès kolegijos) ir aukštesniujų mokyklu (Panevėžio Domaševičiaus medicinos mokyklos, Kauno politechnikumo) studentai, besimokantys ivairiuose Lietuvos regionuose. Renkantis lizdus atsižvelgta ne tik i geografini, bet ir i daugybę kitú veiksnių, pavyzdžiui, studiju krypti, universiteto prestižą ir pan. Pagrindine tiriamujų imtis sudaryta iš $78 \%$ universitetų, $14 \%$ aukštesniujų ir $8 \%$ kolegijų studentų (atitinkamai Lietuvos universitetuose studijuoja $72 \%$, aukštesniosiose mokyklose $21 \%$ ir kolegijose $7 \%$ studentu). Norint duomenis palyginti ir užtikrinti geresnę požymių statistinę sklaidą, ¡̇ imtį itrauktos kontrolinès-kontrastinès grupès: vyresniujų vidurinių mokyklų ir gimnazijų moksleivių, jaunų bedarbių, politinių kalinių ir tremtinių, vyresnių nei 40 metu amžiaus asmenų grupès. Iš viso apklausti 1002 respondentai, iš jų 71\% $(\mathrm{n}=712)$ studijuojantis jaunimas. Šios imties (studentu) pagrindinès demografinès charakteristikos yra tokios: vyru $-39,6 \%$, moteru $-60,4 \%$, amžius svyruoja nuo 18 iki 29 metu (Mean $=21,8 \mathrm{~m}$.; $\mathrm{SD}=4,84 \mathrm{~m}$.).

Užduotis ir tyrimo eiga. Empirinis Lietuvos akademinio jaunimo emigracinių nuostatų tyrimas atliktas naudojant originalų uždaro tipo anonimini klausimyna, i kurị buvo prašoma atsakyti raštu. Klausimynas sudarytas taip, kad jame išryškètu emigracinès nuostatos (priklausomas kintamasis) ir kiti veiksniai, kurie hipotetiškai mąstant gali paveikti jas ir paaiškinti (nepriklausomų kintamuju blokas).

Kompleksinis klausimynas sudarytas iš keliu dalių. Pirmoje dalyje norima išsiaiškinti socialinesdemografines tiriamujų charakteristikas: amžių, lyti, šeimyninę padèti, tautybę, tèvų ir partnerio tautybę, kalbą, kuri vartojama buityje, socialini-ekonomini statusa. Antroje mèginama atskleisti jaunimo emigracines nuostatas ir jų struktūrą. Abi dalys sudaro A klausimyna, kuris pateiktas respondentams per pirmą tyrimo seriją. Trečia klausimyno dalis skirta nepriklausomiems kintamiesiems išryškinti. Ši klausimyno dalis, sąlygiškai pavadinta klausimynu B, sudaryta iš 13 skalių: gyvenimo ne Lietuvoje patirties, patirties su kitataučiais, religinių ir politinių nuostatų, socialiniu fobijų, vertybinių orientacijų, autokoncepcijos, socialinio tinklo, sveikatos, neurotizmo ir kitų. B klausimynu tiriamieji apklausti per antrą tyrimo seriją. Vèliau apklausos duomenys gauti abiem klausimynais buvo susieti i bendrą statistinę matricą.

Konstruojant matavimo instrumenta, pasirinkta psichometrinè apklausos prieiga. Tai reiškia, kad respondentai neprašomi turi patvirtinti faktus, bet jų nuostatos atskleidžiamos netiesiogiai, iš eilès dažnai nenuosekliai pateikiamų teiginių. Šių teiginių arba testo žingsnių pagrindu vẻliau parengtos skalès. Iš viso kompleksinè anketa sudaryta iš 605 testo žingsnių. Rengiant visumą, pasirinkti keli atsakymo formatai, tačiau dažniausiai tiriamieji prašomi pasirinkti atsakymo variantus penkių pakopu Likerto skaleje nuo „visiškai sutinku“ iki „visiškai nesutinku“". 


\section{REZULTATAI}

Pirma tyrimo dalis orientuota i priklausomojo kintamojo - emigracinių nuostatų, jų dimensiju ir kintamujų atskleidima, antrą — i ryšių tarp emigracinių nuostatų ir nepriklausomų kintamujų, t. y. psichosocialinių veiksnių išsiaiškinimą.

Tiriamiesiems pateikta grupe pirminių teiginių (14 Items), parodančiu gana plačią požiūrių i emigraciją skalę. Teiginiai, sutankinti faktorių analizès būdu, atskleidžia emigracinių nuostatų konstrukto struktūrą, kuri yra parodyta lentelèje. Faktorių patikimumo būdu išskirtos trys Lietuvos studentu nuostatu dimensijos ir atitinkamai subskalès: „racionalus“, „etnocentristinis“ ir ,ekonomiškai motyvuotas (kosmopolitinis)“" požiūris ị emigraciją.

Tiek atsakymų i pavienius klausimus struktūra, tiek apibendrinti skalių parodymai liudija ganètinai aiškias tendencijas. Matyti, kad studijuojančio jaunimo populiacijoje dominuoja „racionalus“ požiūris i emigraciją (vidutinis pritarimas - 75,2\%). „Racionaliu“ požiūriu pavadintas ekstrahuotas faktorius, susidedantis iš tokiu teiginiu kaip: $A \check{S}$ norèčiau gyventi užsienyje, jei būčiau tikras, kad gausiu ten norima išsimokslinima ir darba; Palikčiau Lietuvq tik tada, jeigu užsienyje manęs lauktu ¿domi veikla, mylimas žmogus ir pan.
Vidutinis pritarimas ,etnocentristini““ ir „kosmopolitinį“ požiūrị i emigraciją rodantiems teiginiams yra daug mažesnis. Vis dèlto „etnocentristiniam“ požiūriui pritariančių yra šiek tiek daugiau - 46,5\%. Šiai nuomonei atstovauja asmenys, kurie nenoretu išvykti iš Tẻvynès, nes užsienyje ilgai neištvertu, nes jiems sunku isivaizduoti savo gyvenima be Lietuvos ir pan. Kiek mažesnis pritarimo reitingas „ekonomiškai motyvuotam (kosmopolitiniam)“ požiūriui į emigraciją - 44,2\%. Šie asmenys svajoja apie gyvenimą Vakaruose ir yra pasiryžę ten vykti bet kokiomis sąlygomis: legaliomis, nelegaliomis ar net kriminalinėmis (Aš sutikčiau vykti užsidirbti ¿ kita šali bet kokiomis salygomis, net rizikuodamas sveikata, o gal net gyvybe).

Taikant klasterinę analizę, gauti tiriamosios imties statistiniai tipai, susiklostę pagal emigracines nuostatas. Statistiniai tipai parodyti paveiksle.

Parinktas dviejų klasterių (grupiu) modelis. Paaiškejjo, kad pagal šį modeli, egzistuoja dvi apylygès (pirmos grupès $\mathrm{n}=331$, antros $-\mathrm{n}=351$ ), tačiau ganètinai skirtingos požiūriu į emigraciją studentu grupès. Pirma grupè sąlygiškai pavadinta „,mobilaus kosmopolitinio“ tipo grupe, yra menko „etnocentrizmo“, bet aukšto „ekonomiškai motyvuoto (kosmopolitinio)“ ir „racionalaus“" požiūrio į emigraciją. Šiai grupei priklausantys asmenys nèra aklai susi-

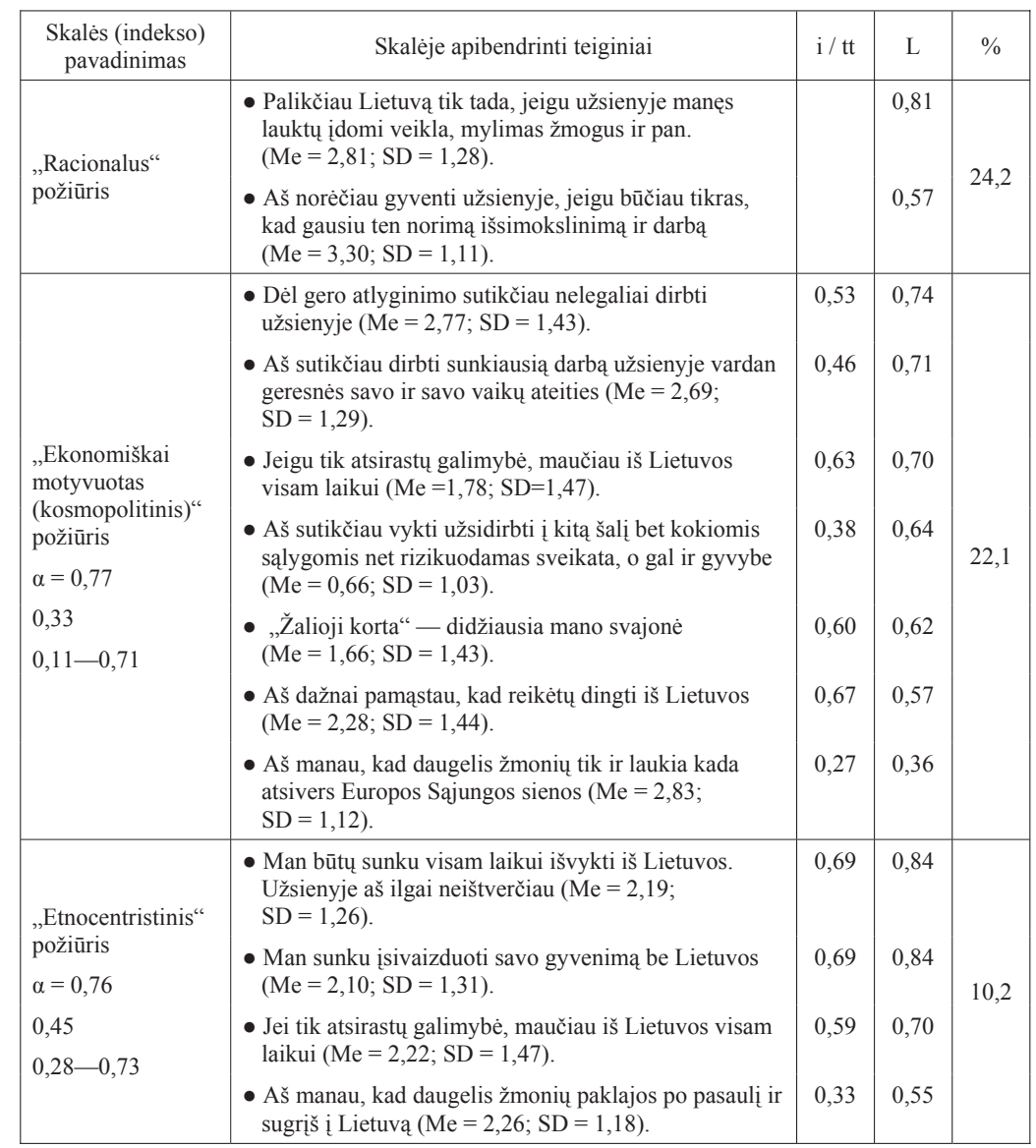

Lentelè. Emigracinių nuostatų skalè

Pastaba. Lenteleje pateikti statistiniai rodikliai: 1) Kronbacho alfa koeficiento reikšmès; 2) vidutinè interkoreliacija tarp testo žingsnių, minimali ir maksimali koreliacija; 3) i / tt - skiriamoji geba; 4) L - faktoriu svoris; 5) faktorių modelio bendroji paaiškinta sklaida. 
Pav. Studentų statistiniai tipai, susiklostantys pagal „etnocentristinį“, „racionalų“ ir ,ekonomiškai motyvuotą (kosmopolitinị)“ požiūrị ị emigraciją

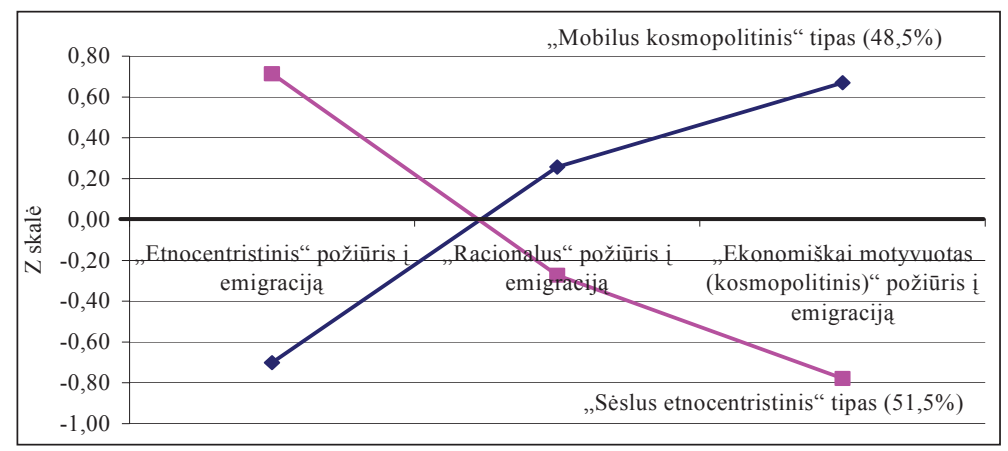

fakto, kad žmonès linkę migruoti iš mažiau turtingu i turtingesnius kraštus, ieškodami darbo, didesnio atlygio, siekdami geresnio išsimokslinimo ir pan.

Lyginant ši emigracinių nuostatų tyrimą su anksčiau Lietuvoje atliktais (Kuzmickaite, 1994, 1996; Matonytė, 2001), galima ižvelgti tam tikrų skirtumų. Padidejo asmenų, norinčių išvykti iš Lietuvos visam laikui, skaičius. 1994 m. duomenimis, nuolatos gyventi užsienyje norèjo $15 \%$, 1996 m. - 7\%, o šio tyrimo duomenimis - jau apie $30 \%$ apklaustujų. Šiek tiek pasikeitè potencialios emigracijos kryptys. Geidžiamiausia šalimi liko Jungtinès Amerikos Valstijos, bet Vokietiją, kuri anksčiau konkuravo su JAV, šio tyrimo metu pasirinko tik 12,8\% apklaustuju, tuo tarpu $1994 \mathrm{~m}$. tokių buvo $25 \%$, o $1996 \mathrm{~m}$. - 32\%. Lietuvos elito tyrimas (2001 m.) parode, kad daugelis iš jų labiausiai $(40 \%)$ norètu gyventi Vokietijoje ir šiek tiek mažiau (33\%) - JAV (Matonytė, 2001). Sumažèjo norinčiujų vykti ị Skandinavijos šalis. Lietuvos gyventojai tradiciškai simpatizuoja gana plačiai reklamuojamam Tibetui. Visgi pasirodè, kad pasirinkimą iš esmès lemia ne ideologija ar gyvenimo būdas (Tibeto nepasirinko nè vienas tiriamasis), o kokybė. Taigi šio tyrimo metu, kaip ir kitų, pastebėtas stabilus ekonominis emigracijos motyvas.

Siekta išsiaiškinti, kaip studentų emigracinès nuostatos susijusios su jų socialiniu-ekonominiu statusu. Tuo tikslu tiriamieji buvo prašomi anketoje nurodyti savo asmenines ir šeimos vidutines mènesines pajamas. Paaiškejjo, kad šeimos pajamų dydis asmens emigracinėms nuostatoms itakos neturi. Tačiau asmeniniu pajamų dydis su emigracinėmis nuostatomis statistiškai susijęs. Kuo mažesnès asmeninès pajamos, tuo labiau išreikštas ekonomiškai motyvuotas „kosmopolitinis“ požiūris i i emigraciją, Pirsono koreliacijos koeficientas $r=-0,189(p=0,000)$. Taikant $\chi^{2}$ kriterijų, gauta šio rodiklio reikšme lygi 24,674 $(\mathrm{p}=0,000)$. Kuo didesnès asmeninès pajamos, tuo didesné „etnocentristinio“ požiūrio ị emigraciją tendencija $(\mathrm{r}=0,155 ; \mathrm{p}=0,000)$. Taikant $\chi^{2}$ kriterijų nustatyta: $\chi^{2}=20,135 ; p=0,000$. Šios hipotezès 
tikrintos taip pat ir naudojant vienfaktorinès analizès modeli. Abiem atvejais gauta, kad daroma išvada yra statistiškai patikima $(\mathrm{p}=0,000)$. Tai, kad šeimos pajamos jaunuolių emigracinèms nuostatoms itakos nedaro, bet jas paveikia asmeninių pajamú dydis, gali būti paaiškinama kaip tam tikra emancipacijos arba modernizacijos išdava. Kiekviena šeima daugiau ar mažiau remia studijuojanti jaunuoli, tačiau dažniausiai ši parama teikiama mokslui, sveikatos priežiūrai, mitybai bei panašioms reikmėms, bet ne jauno žmogaus igeidžių pramogoms, savitam gyvenimo stiliui ir pan. tenkinimui.

Palyginus, kaip skiriasi vyru ir moterų emigracinès nuostatos pagal asmenines pajamas, gauta, kad vyrų ekonominès migracijos nuostatos išreikštos stipriau negu moteru. Hipotezè buvo tikrinta naudojant t testą, taikomą nepriklausomoms imtims $(\mathrm{t}=4,001 ; \mathrm{p}=0,000)$.

Pastebèta ir daugiau bendrų tendencijų. Pavyzdžiui, didejjant tiriamujų amžiui silpnèja ekonomiškai motyvuotas ,kosmopolitinis“ požiūris i emigraciją; vedę (ištekèjusios) labiau laikosi sèslios, etnocentristinès pozicijos; labiausiai išvykti iš šalies norètų didžiujų miestų, mažiausiai — sostinès gyventojai; ,etnocentristiškiausiai“‘ apie emigraciją mano studentai, kilę iš vietovių, kuriose lietuviai pagal tautinę sudèti sudaro 90-95\% gyventojų, o „kosmopolitiškiausiai“ — užaugę vietovėse, kur lietuvių yra tarp 70—90\%.

Dar vienas tyrimo tikslas — apčiuopti jaunimo emigracinių nuostatų ir kai kurių psichosocialinių charakteristiku statistines sąsajas. Tyrimo nepriklausomi kintamieji, t. y. psichosocialiniai veiksniai sudaro du blokus: pirma, ivvairios pasaulèžiūrinès nuostatos, tokios kaip požiūris į kitataučius, integracinès, religinès, tautinès bei politinès; antra, asmens vidinès psichologinès būsenos, t. y. socialinès fobijos, darbinès raiškos aspiracijos, autokoncepcija, nepalanki psichologinè būsena, taip pat vertybinès orientacijos. Nepriklausomojo kintamojo skalių struktūrai atskleisti iš viso panaudotas 571 testo žingsnis. Kadangi tyrimas labai platus, tai straipsnyje pristatyti visus gautus rezultatus problemiška. Plačiau susipažinti su tyrimo duomenimis galima ataskaitoje Lietuvos valstybiniam mokslo ir studiju fondui.

\section{IŠVADOS}

1. Psichometrinio tyrimu, taikant faktorių patikimumą, išskirti trys Lietuvos studentų emigracinių ketinimų nuostatų rodikliai: 1) ,Racionalus požiūris“; tipinis subskalès teiginys —Palikčiau Lietuva tik tada, jei užsienyje manęs lauktu idomi veikla, mylimas žmogus ir pan. Vidutinis pritarimas tokio pobūdžio teiginiams siekia 75,2\%. 2) „Etnocentristinis požiūris“; tipinis subskalès teiginys - Man būtu sunku visam laikui išvykti iš Lietuvos... Vidutinis pritarimas tokio pobūdžio teiginiams siekia 46,5\%. 3), Ekonomiškai motyvuotas (kosmopolitinis) požiūris"; tipiniai subskalès teiginiai —Žalioji korta — didžiausia mano svajonè arba Dèl gero atlyginimo aš sutikčiau nelegaliai dirbti užsienyje. Vidutinis pritarimas tokio pobūdžio teiginiams siekia 44,2\%.

2. Klasterinès analizès būdu buvo rasti du Lietuvos studentų statistiniai tipai, susiklostantys pagal emigracinių nuostatų raišką: 1) ,Etnocentristiškai nusiteikęs (sėslus)“ tipas, kurio santykinis paplitimas šalies studentų populiacijoje siekia apie 51,5\%. 2) ,Ekonomiškai motyvuotas, kosmopolitiškai nusiteikęs (mobilus)“" tipas, kurio santykinis paplitimas šalies studentú populiacijoje siekia apie 48,5\%.

3. Lietuvos studentų emigracines nuostatas ir emigracinius ketinimus sistemingai paveikia socialiniai-demografiniai kintamieji. Nustatytas paveikumas daugeliu atvejų teoriškai prasmingas ir statistiškai patikimas. Moterys, vertindamos savo galimus emigracinius ketinimus, labiau išreiškia ,etnocentristinị“ požiūrį, vyrai šiuo požiūriu sąlygiškai stipriau išreiškia ,ekonomiškai motyvuotą (kosmopolitini)" požiūrị; atitinkamai vedę studentai linkę atstovauti ,etnocentristinėms“" pažiūroms, o nevedę — ,ekonomiškai motyvuotoms (kosmopolitinèms)“. Simptomiška, kad pastaraji požiūrị sąlygiškai stipriau išreškia jaunesni ir mažiau išsilavinę studentai.

4. Lietuvos akademinio jaunimo emigracines nuostatas ir emigracinius ketinimus sistemingai paveikia asmens bei jo psichosocialinès situacijos charakteristikos (tautinis identitetas; vertybės; autokoncepcija; domejjimasis politika; samprata apie krašto gerovę; savo profesinès perspektyvos vertinimas; išgyvenamos socialinès fobijos; savo sveikatos būklès vertinimas; intymaus gyvenimo vertinimas; požiūris ị studijas ir darbą; kai kurie socialinio tinklo parametrai ir kt.). Minėti sąryšiai yra: a) statistiškai reikšmingi; b) teoriškai prasmingai interpretuojami.

Padẻka. Autoriai nuoširdžiai dẻkoja Lietuvos valstybiniam mokslo ir studijų fondui, finansavusiam ši tyrimą. 


\title{
LITERATŪRA
}

Bernstein, J. H., Shuval, J. T. (1996). Occupational Continuity and Change Among Immigrant Physicians from the Former Soviet Union in Israel. International Migration, 33, 3-25.

Eckstein, Z., Weiss, Y. (1997). The Absorbtion of Highly Skilled Immigrants: Israel 1990-1995 [S. I.], 6-7.

International Migration Report. (2005). New York: United Nations Publication.

Jucevičienè, P., Jucevičius, G., Viržintaitè, R. (2000). „Protu nutekejjimo" reiškinys ir jo atspindžio Lietuvos intelektualiniame kapitale bruožai: žvalgomasis tyrimas (Tyrimas atliktas KTU Edukologijos institute Lietuvos Mokslo tarybos užsakymu).

Kazlauskienè, A. (2001). Ekonominès migracijos raida Europoje ir Lietuvoje. Sociologija: praeitis, dabartis, perspektyvos. Kaunas: Technologija.

Kuzmickaite, L. (1994). Lietuvių teritorinio identiteto empiriniai tyrimai. Sociologija Lietuvoje: praeitis ir dabartis. Kaunas: Technologija.

Kuzmickaite, L. (1996). Migraciniai procesai ir paribio gyventojų nuostatos išvykti iš Lietuvos. R. Grigas (Red.), Paribio Lietuva. Vilnius: Rosma.

Lietuvos statistikos metraštis. (2001). Vilnius: Statistikos departamentas prie Lietuvos Respublikos Vyriausybės.
Matonyte, I. (2001). Posovietinio elito labirintai. Vilnius: Knygiai.

Matsumoto, D. (2000). Culture and Psychology: People Around the World. New York: Wadsworth.

Pellegrino A. (2001). Trends in Latin American Skilled Migration: "Brain drain" or "brain exchange". International Migration, 39 (5), 111-132.

Sipavičienè, A., Tureikytè, D. (2000). Nelegali migracija Lietuvoje: retrospektyva ir šiu dienu problemos. Vilnius: Vilniaus universitetas.

Stankūnienè, V. (1996). Mobility of Scientists in Lithuania: Causes and Strategies of Behavior. Changes of Identity in Modern Lithuania. Vilnius: LFSI, Goteburgo universitetas. P. 336-354.

Tarptautinè migracija. (2004). Prieiga per internetą: http:// www.std.lt/Statistika/Gyventojai/Migracija.htm

Thomas, A. (1993). Kulturvergleichende Psychologie: Eine Einfuhrung. Gottingen: Hogrefe.

Гохберг, Л., Миндели, Л., Некипелова, Е. (1994). Эмиграция учёных: проблемы и реальные оценки. А. Азраэль (Ред.), Миграция спещиалистов России: причины, последствия, оценки. Москва: ИНП РAH, RAND США. С. $13-18$.

\section{EMIGRATIONAL ATTITUDES OF LITHUANIAN STUDENTS AND THE FACTORS INFLUENCING THEM}

\author{
Gediminas Merkys, Viktorija Baršauskienė, Dalia Antinienė \\ Kaunas University of Technology, Kaunas, Lithuania
}

\begin{abstract}
This report reveals the empirical research data of the attitudes of Lithuanian students concerning emigration. Social attitudes were analysed by employing a closed type anonymous questionnaire. The questionnaire was constructed in such a way that it could reflect emigrational attitudes of the students (dependent variable), as well as other factors, which, thinking hypothetically, can have an influence on the intentions to emigrate and can be a clue to explain them (the block of independent variables). 712 students were questioned. The research was done in five cities of the country, in 9 universities, 2 colleges and 2 higher schools. Alongside with the main group there was an additional group of 290 respondents, the so called "contrasting" respondents, comprising different age and social status groups, starting from schoolchildren and adults of more advanced age till elderly people, including political prisoners and those who lived in exile.

The dependent variable was revealed with the help of 14 questions, from which, by means of factor analysis, three psychometric indexes were comprised. The independent variable was made concrete with the help of 571 questions. From them, by means of multilevel factor analysis, psychometric indexes were made. Later on combined structures of dependent and independent variables were associated together statistically, by employing various methods - correlative analysis, regressive analysis, dispersive analysis etc.

While evaluating their intentions to emigrate, the students tend to represent a rational attitude to this phenomenon, but not an economically motivated "cosmopolitan" viewpoint. Younger and less educated students tend to agree with the latter view. In the context of emigrational intentions women are prone to take an ethnocentric position, while men choose an economically motivated one. Due to cluster analysis two different student types (concerning emigrational intentions) were discovered - "the mobile cosmopolitan" (spread about 48.5\%) and "settled ethnocentric" (spread about 51.5\%). It became clear that emigrational intentions of students theoretically meaningfully and statistically reliably are connected with various variables, that reflect students' personality parameters and their psychological status.
\end{abstract}

Keywords: emigrational attitudes (attitudes concerning emigration), cosmopolitan, rational and ethnocentric attitudes to emigration.

Gauta 2006 m. vasario 10 d.

Received on February 10, 2006

Priimta 2006 m. gegužès $25 \mathrm{~d}$.

Accepted on May 25, 2006

\author{
Dalia Antinienè \\ Kauno technologijos universitetas \\ (Kaunas University of Technology) \\ K. Donelaičio g. 20, LT-44239 Kaunas \\ Lietuva (Lithuania) \\ Tel +370 37771174 \\ E-mail daliaan@takas.1t
}

